he met his countryman, Andreas Friedrich Bauer (1783-1860), who possessed the mechanical skill Koenig lacked. Four patents were taken out between 1810 and 1814 and from these came the powerdriven flat bed printing machine in which the paper was pressed against the type by a cylindrical roller. Through John Walter (1776-1847), two of Koenig's machines were installed for printing the Times, and with the appearance of the issue of November 28, 1814, a new era in newspaper production began. Koenig's success, however, was but the prelude to a long struggle against difficulties. Returning to Germany with Bauer in 1817, he founded a works for the building of printing machines at Oberzell near Würzburg, only to find it next to impossible to obtain properly skilled artisans. Five years indeed passed before the partners completed their first German printing machine, and throughout his life Koenig met with little but adversity. He died at Oberzell at the age of fifty-eight years. The business was carried on by Bauer and relations, and afterwards gained a wide reputation. The speed of an early Koenig machine was about two thousand sheets an hour. Improvements by Cowper and Applegarth raised the speed to 5,000-10,000 sheets an hour, the Hoes of America then built machines doubling the capacity and to-day the rate of printing is some fifty times as fast as that in 1814 .

\section{Royal Academy Winter Exhibition}

OF the Winter Exhibition of the Royal Academy, illustrating the works of members who have recently died, one of the oldest academicians remarked that in no country could be brought together such a fine collection of sound painting from the work of men recently with us. Apart from merit, there is also the pleasure of seeing again pictures notable in their day, some of enduring appeal, while others markedly exhibit the fashion of another age. Both as regards number and interest, Orpen's pictures should be mentioned first. From the student-study, the "Hamlet Play Scene", with its dull browns and reds, the transition can be traced to the clear coldness of the colours in his recent portraits, well on the way to be 'old masters'. One of the most striking, that of the late Sir William McCormick (No. 87), will delight many readers of NATURE. Mid-Victorian days are recalled by the work of the late president, when the fashion was for stained glass windows, flowing garments and red-gold hair. Time was when in every annual exhibition one or more of Harry Tuke's pictures of bathing boys appeared. Here we have a collection of them and find them still pleasing, while Wyllie's sea-pictures are full of life and colour. In contrast with these the Lambert pictures seem wanting in atmosphere, but that of the Red Girl (No. 251) and Round Mirror (No. 260) should be noticed.

Perhaps too low in tone for modern taste are the pictures of La Thangue, in which French influence is prominent. Great variety is shown in the works of Greiffenhagen, some of it almost heraldic, but including several character studies (Nos. 304, 306 and 325). Of contrast between an earlier and a later style there is none more violent than is exhibited in the work of Sims, from a delicate and poetic touch portraying in delicate mother-of-pearl tints the "Light that never was on Sea or Land", to strange conceptions in harsh reds, yellows and blacks. Many examples of the well-known work of Ricketts as a book-designer will be found in a case in Room IX, while his paintings are hung in the same room against a rose background. Great restraint is shown in the water-colours of David Muirhead, but more freedom is exhibited in his oil-paintings $(543,547)$.

\section{Education for Industrial Management}

Over the signatures of Lord Rutherford, Sir William Bragg, Sir Josiah Stamp, Lord Eustace Percy, Lord Amulree, Sir Herbert Austin, Prof. C. E. Inglis, Sir Francis Goodenough and others, an important manifesto on "The Management Factor in Industry" was issued on December 31. The manifesto was drafted by a small committee all the members of which are voluntary workers in one or more societies or institutions dealing with functional phases of management. Of this committee, Mr. E. S. Byng was chairman and Mr. S. Townsend, honorary secretary. The manifesto emphasises the urgent need for a full appreciation of the national importance of the management function and of the rapid diffusion of management knowledge, and directs particular attention to the quality of industrial management. Systematic education for management is asserted to be one of the chief steps required to assure Britain's industrial future, and neglect of this factor is frequently responsible for our managers' failure to interpret the progress of science in terms of their own undertakings. The manifesto directs attention to the development of a science of management and points out that to an increasing degree men of high personal character and cultured vision are finding in manage. ment a sphere of high social service. They are using the resources and methods of science to raise the effectiveness of their contribution to the organisation and direction of industry.

WHILE on this side the application of scientific methods to the functions and processes of business organisation promotes greater efficiency, establishes standards, and replaces haphazard effort by the deliberate pursuit of predetermined objectives, management is also an art involving co-operation and understanding of the human factor, so that acceptance of the scientific principles and loyal co-operation in the plans of the organisation may be secured from all its members. Skill in technique; knowledge of workshop practice; sympathy with the human factor; a receptive mind and an international outlook-these elements combine to produce a type of management which represents both in purpose and in method a second industrial revolution. Attention is directed to the assistance which statistical science can give in the higher control of industry, whether in budgetary matters, departmental cooperation and responsibility, planning of sales and production or costing methods, and it is pointed out 